Article

\title{
Exploring the Effect of Different Performance Appraisal Purposes on Miners' Organizational Citizenship Behavior: The Mediating Role of Organization Identification
}

\author{
Hui Lu *, Ailing Yue, Yu Han and Hong Chen * \\ School of Management, China University of Mining and Technology, Da Xue Road 1, Xuzhou 221116, China; \\ ailing5100@126.com (A.Y.); hanyu232426@163.com (Y.H.) \\ * Correspondence: 3384@cumt.edu.cn (H.L.); hongchenxz@163.com (H.C.)
}

Received: 24 October 2018; Accepted: 14 November 2018; Published: 17 November 2018

\begin{abstract}
This study theorized and examined the effect of performance appraisal purposes on miners' organizational citizenship behavior (OCB) via organizational identification. Survey data from 700 miners in state-owned Chinese coal mine enterprises were analyzed using multiple regression and bootstrap sampling. Results indicated that both developmental purpose of the performance appraisal and evaluative purpose of the performance appraisal had positive effects on overall OCB and its four dimensions via organizational identification. Furthermore, developmental purpose of the performance appraisal had a stronger relationship with overall OCB and its four dimensions than evaluative purpose of the performance appraisal. This study provides practical guidance to assist Chinese and even Asian coal mining enterprises in deciding how to motivate miners' OCB through improving a performance appraisal system and how to strengthen miners' organizational identification.
\end{abstract}

Keywords: organizational citizenship behavior; performance appraisal purposes; organizational identification; coal mine enterprises

\section{Introduction}

In recent years, the numbers of coal mining accidents and resulting deaths in China have decreased. According to 2016 data from the State Administration of Coal Mine Safety of China [1], 249 coal mining accidents and 538 mining deaths occurred in China, 29.3\% and 10\% fewer, respectively, than in 2015 . However, the mortality of one million tons of coal of China in 2016 is 0.106 , which is much higher than that of United States in 2004 since it is only 0.027 [2]. Lowering the number of coal mining accidents remains a crucial problem to be solved urgently for coal mining enterprises in China. Studies have indicated that the proportion of coal mining accidents caused by unsafe behavior has increased to $80 \%[3,4]$, which indicates that miners' unsafe behavior is the main cause for the high rate of accidents. In practice, the traditional security management of China's coal mining industry pays attention to the mandatory control [5] and punishment [6] of miners' unsafe behaviors; these approaches by authority can influence miners' attitude and behavior so as to reduce the occurrence of safety accidents somewhat [7], but easily lead to transient, passive, and negative safety behaviors of miners [8] and are subsequently harmful to the persistence, conscientiousness and positivity of miners' safety behaviors. Conversely, organizational citizenship behavior (OCB) highlights the autonomy, dedication and persistence of employee behavior when employees actively maintain their organization interests in the workplace [9-11]. Thus, OCB is able to enhance miners' sense of responsibility for improving the level of organization safety [12] and therefore effectively reduce the rate of accident occurrence [13]. 
The degree of autonomy and persistence of miners' safety behaviors can be improved through encouraging and strengthening their $\mathrm{OCB}$, which makes a positive contribution to the promotion of enterprises' safety performance [14].

Moreover, numerous studies have shown that the human resource management practices (such as performance appraisal) used by enterprises have a direct impact on employees' attitude and behavior [15-17]. Furthermore, high-performance human resource management practices can significantly promote OCB of employees [18]. As an important tool of human resource management practice, the purposes of performance appraisal (i.e., the ultimate goals for which an organization use performance appraisal as a tool) that employees perceive [19] can affect employee's positive behaviors directly [20]. Two types of performance appraisal purposes are common: developmental purpose of the performance appraisal and evaluative purpose of the performance appraisal [21]. Performance appraisal purposes differ in their degree of impacts on employees' positive behaviors [18]. Accordingly, an obvious question is whether miners' OCB is promoted when the development purpose of the performance appraisal and evaluative purpose of the performance appraisal are scientifically incorporated into safety management of Chinese coal mining enterprises that have obvious characteristics of extensive management. A few scholars have discussed the relationship between developmental performance appraisal and OCB [22]. However, differential studies that test the effects on OCB of separating developmental and evaluative purposes of the performance appraisal are rare.

In addition, types of performance appraisal practices affect employees' workplace behaviors by mainly influencing their attitudes [18]. Therefore, the attitude variables are the key variables that connect performance appraisal purposes and OCB [23,24]. An important variable measuring employee's attitude is organizational identification, which is defined as the consistency of individual values and organizational values and individual emotional attachment to an organization as a member of the organization [25]. Organizational identification is not only affected by the performance appraisal purposes [26], but also plays an important role in employees' workplace behaviors [27]. Organizational identification may serve as a mediating variable between performance appraisal purposes and miners' OCB.

There is a large body of literature in relation to OCB that involves industries such as general services, banking and financial services, and manufacturing [28], the state electrical grid industry [29], the technology industry [30], and the education industry [31]. The antecedent variables of OCB have been explored from four aspects: individual characteristic variables, task characteristic variables, organizational characteristic variables, and leadership variables. Research about individual characteristics involves aspects of job satisfaction [32], job insecurity [29], organizational commitment [33], organizational justice [34], age [35], gender [36], years of service [37], and education [38]. Research about task characteristics examines task routine [39], task feedback [40], and internal incentives of tasks [41]. Research about organizational characteristics focuses on organizational culture [42], organizational structure (e.g., hierarchy and forms of control) $[43,44]$ and organizational type [45]. Research about leadership variables concerns transformational leadership [46], transactional leadership [47] and psychological contract [48]. Existing research related to coal mining enterprises has tended to focuses on human factors of accidents such as deliberate violation behaviors [49], counterproductive work behaviors [50], and risk-taking behaviors [51]. Whereas several researchers have studied safety management practices in coal mining enterprises from the perspective of miners' OCB promotion. Among these studies is research about the relationship between safety climate and safety citizenship behavior [52], but even this research ignored the effect of performance appraisal purposes in coal mining enterprises on OCB.

Accordingly, in this paper we assess the effect of two purposes of performance appraisal, as well as of the level of organizational identification, on the OCB of miners in Chinese mining enterprises in order to help enterprises managers identify the differential effect of different performance appraisal purposes on employees OCB and organizational identification, and then design performance 
appraisal system based on different purposes to achieve organization strategy. Our study enriches the theoretical research on miners' OCB in coal mining enterprises to provide a reference for future research. Furthermore, this paper provides guidance for standardizing miners' workplace behaviors and promoting the level of safety management in coal mining enterprises through human resource management practices.

\subsection{The Performance Appraisal Purpose and $O C B$}

There has been extensive research on the connotation and structure of employees' OCB. Organ [9] defined OCB as "individual behavior that is discretionary, not directly or explicitly recognized by the formal reward system, and that in the aggregate promotes the effective functioning of the organization". Among research about OCB characterized by Chinese native culture, one of the best-known studies is that of Farh et al. [41], which divided OCB into four levels based on a sample of employees in organizations in mainland China: individual level (including self-learning, taking initiative, and keeping work place clean), group level (including interpersonal harmony and helping coworkers), organization level (including exhibiting voice behavior, protecting and saving company resources, and participation in group activities), and society level (social welfare participation and promoting company image).

The applicable characteristics of OCB structure are different in different cultural contexts [53]. Because participants of our research are miners working in Chinese coal mining enterprises, the cultural context is consistent with the Chinese social cultural context in which Farh et al. [41] explored OCB structure. Therefore, the four-dimension OCB of Farh et al. [41] based on Chinese native cultural context was considered to be more suitable for our research than other OCB structural definitions.

The purpose of performance appraisal is the employees' perception of the ultimate purposes for which an organization desire to use performance appraisal as a tool [19]. Performance appraisal purposes includes two types: developmental and evaluative purposes [19,21]. The developmental purpose of the performance appraisal focuses on improving employees' work skills and experiences, including identifying individual's strengths and weaknesses, and identifying training needs, etc. In contrast, evaluative purpose of the performance appraisal is concerned with comparing an individual's performance to a set standard, to the individual's previous performance, or to the performance of other organizational members [54].

The general application of mechanization in the coal mining industry requires higher skill levels of miners, and the generational differences in miners' work values are also becoming more pronounced as the average age of miners continues to decrease [55]. Compared with elder miners who care more about extrinsic values such as salary and welfare, younger miners pay more attention to intrinsic values such as personal skills improvement and career development [56]. As noted previously, the developmental purpose of the performance appraisal mainly helps miners improve their work skills and ability; this type of appraisal can meet the miners' demand for self-development and subsequently motivate miners to learn actively, that is, to promote individual-level OCB [22,57]. At the same time, because it is an effective tool for improving miners' work skills, developmental purpose of the performance appraisal reflects long-term and voluntary organizational support and investment in miners as individuals. According to social exchange theory, miners tend to reward organizations that are perceived to offer support and investment to them [58], which is shown as mutual help and cooperation with colleagues at the group-level OCB [59]. Because developmental purpose of the performance appraisal provides miners with a positive and supportive work environment, miners' job satisfaction and organizational identification will be higher. Thus, miners are more likely to safeguard the overall interests of the organization and achieve organizational goals [60] through OCB [60,61]. Thus, the following hypothesis is proposed.

Hypothesis 1a. The developmental purpose of the performance appraisal is positively related to overall OCB and its four dimensions of miners. 
Evaluative purpose of the performance appraisal refers to assessment by coal mining enterprises of previous work performance of miners; the appraisal results are used as the basis of human resource activities such as salary decision-making, promotion, and retention or dismissal decisions [54]. However, evaluative purpose of the performance appraisal is unable to satisfy miners' professional development demands for identifying their own strengths and weaknesses and improving work skills; thus, this type of appraisal purposes tends to inhibit employees' initiative and enthusiasm to maintain interests of the organization. As a consequence, individual-level OCB such as taking initiative is reduced [62]. Moreover, evaluative purpose of the performance appraisal also judges the "good" and "bad" among miners according to assessment results, which can cause conflicts between employees and aggravate their insecurity and competitive pressures, and subsequently increase the vicious competition between miners and the decline of group-level OCB such as helping colleagues [63]. Moreover, evaluative purpose of the performance appraisal will enhance the degree of adhesion between the results of performance appraisal and the individual benefits, which will lead to the outcomes that miners only focus on their own interests rather than collective and organizational interests [64], and reduce organization-level OCB. In addition, the social-level OCB will also be reduced due to miners ignoring the enterprise's image in society. Thus, the following hypothesis is proposed.

Hypothesis $\mathbf{1 b}$. The evaluative purpose of the performance appraisal is negatively related to overall OCB and its four dimensions of miners.

\subsection{The Mediating Effect of Organizational Identification on the Relationship between Performance Appraisal Purposes and $O C B$}

With the increasing proportion of younger employees in coal mining enterprises, the personal needs of miners gradually shift from attention on extrinsic rewards such as salary and welfare to a focus on intrinsic rewards such as promotion of personal ability and career development. Developmental purpose of the performance appraisal focuses on skills-upgrading and career development planning of miners. It can provide miners with a supportive institutional environment encompassing diverse skills training and broad career paths based on their self-characteristics [65]. Thus, developmental purpose of the performance appraisal is consistent with an individual's intrinsic needs, which will stimulate miners' organizational identification [26]. Thus, the following hypothesis is proposed.

Hypothesis 2a. The developmental purpose of the performance appraisal is positively related to miners' organizational identification.

Individuals with strong organizational identification tend to protect the overall interests of the organization and take actions that are beneficial to the organization so as to make the organization succeed $[66,67]$. For instance, miners will undertake self-level OCB, such as actively carrying out extra vocational training, to promote their work skills and subsequently reduce the safety risks in the workplace [68]. Group-level OCB, such as helping coworkers, is performed to promote interpersonal harmony [69]. Organization-level OCB, such as protecting and saving company resources, is carried out to help enterprises reduce production costs [70]. Society-level OCB, such as social welfare participation, is adopted to promote company image [71]. Thus, the following hypothesis is proposed.

Hypothesis $\mathbf{2 b}$. Organizational identification mediates the relationship between developmental purpose of the performance appraisal, and overall $O C B$, as well as its four dimensions of miners.

Evaluative purpose of the performance appraisal uses appraisal outcomes as the basis of rewards and punishments. The relationship between employees and an organization is only a short-term oriented economic exchange [72], which fails to meet the long-term development needs of miners, such as promotion of occupational ability and career development planning, and then undermines 
the organizational identification of miners [59]. Moreover, the evaluative purpose of the performance appraisal will compare advantages and disadvantages between miners based on appraisal outcomes, which will decrease miners' self-esteem and work enthusiasm, and increase work stress and job insecurity, and thereby hinder organizational identification of miners [67]. Thus, the following hypothesis is proposed.

Hypothesis 3a. Evaluative purpose of the performance appraisal is negatively related to miners' organizational identification.

The weakening of organizational identification will reduce miners' sense of responsibility in safeguarding the overall interests of the group and the organization [73], and subsequently result in decreasing OCB that is conducive to the safe operation of coal mining enterprises [74]. For instance, miners will not sacrifice their free time to demonstrate individual-level OCB such as extra occupational training. Miners will ignore the interests of the group, which will lead to the reduction of group-level OCB such as helping coworkers [75]. Moreover, miners tend to focus on personal interests and overlook interests of the organization, and are less likely to perform organization-level OCB such as protecting and saving company resources [70]. In addition, miners will avoid society-level OCB such as social welfare participation that promotes organizational image [76]. Thus, the following hypothesis is proposed.

Hypothesis $3 \mathbf{b}$. Organizational identification mediates the relationship between evaluative purpose of the performance appraisal and overall $O C B$, as well as its four dimensions of miners.

Accordingly, the hypothesized model used in this study is shown in Figure 1.

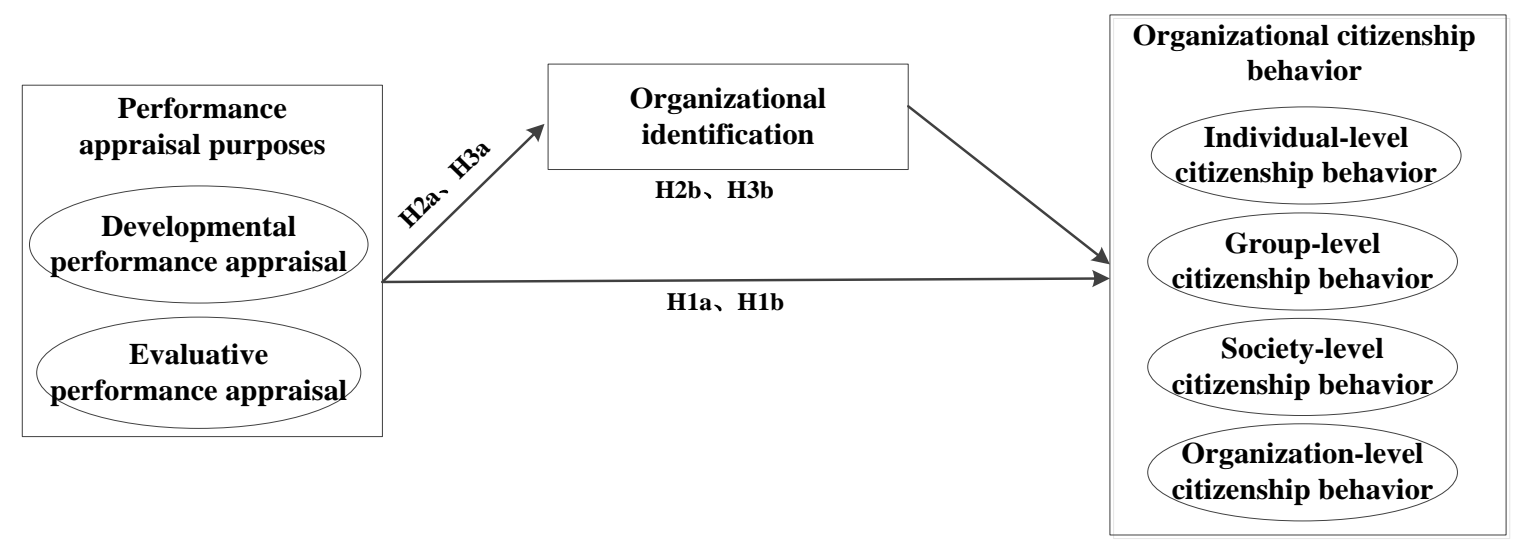

Figure 1. Hypothesized model of the processes linking performance appraisal purpose to organizational citizenship behavior through organizational identification.

\section{Methods}

\subsection{Participants and Procedure}

We studied first-tier miners and foremen in state-owned coal mine enterprises and collected data through questionnaires on the spot. During the survey process, investigators communicated with miners at the first-line miners' pre-shift meeting; this included explaining the questionnaires and answering questions so that miners could complete the questionnaires effectively. The time allowed to finish the questionnaire was limited to 20 to $30 \mathrm{~min}$.

We distributed 1000 questionnaires via face-to-face meetings with miners, and 810 were returned. Of these, 110 invalid copies were discarded for being incomplete, leaving 700 valid questionnaires for analysis ( $86.4 \%$ of the 810 returned). 


\subsection{Measures}

\subsubsection{Independent Variables (Performance Appraisal Purpose)}

The two-dimensional performance appraisal purpose was measured using a nine-item scale developed by Boswell and Boudreau [21]. Developmental purpose of the performance appraisal was assessed using five items. Items included statements such as "performance appraisal identifies my strengths and weaknesses". Evaluative purpose of the performance appraisal was assessed using four items, including statements such as "the results of performance appraisal determine the level of my salary". The respondents indicated their degree of agreement to these items on a five-point scale ranging from "strongly disagree" (1) to "strongly agree" (5). The Cronbach alpha estimates for developmental purpose of the performance appraisal and evaluative purpose of the performance appraisal were 0.849 and 0.898 , respectively.

\subsubsection{Mediator Variable (Organizational Identification)}

The six-item scale developed by Ashforth and Mael [77] for organizational identification has shown high reliability and has been widely used by many scholars, such as Yoshida et al. [78] and Loi et al. [79]. Thus, we also used this scale to measure the miners' levels of organizational identification, including statements such as "When someone praises my organization, it feels like a personal compliment". The respondents used a five-point Likert-type scale to indicate their agreement $(1=$ "strongly disagree" and $5=$ "strongly agree") with each of the items in these scales. The Cronbach alpha estimate for organizational identification was 0.844 .

\subsubsection{Dependent Variables (Organizational Citizenship Behavior)}

OCB was measured using the 30-item scale used by Farh et al. [41] to measure the four OCB dimensions of employees of enterprises in mainland China. Individual-level OCB was measured using eight items with statements such as "I volunteer for overtime work when needed". Group-level OCB was assessed using ten items with statements such as "I help others with urgent and heavy workloads". Organization-level OCB was measured using seven items with statements such as "I save company resources such as electricity and water". Society-level OCB was measured using five items with statements such as "I participate in community service, such as aiding elders in the community". All items were scored on a five-point Likert-type scale $(1=$ "completely disagree" to $5=$ "completely agree"). The Cronbach alpha estimates for individual-level, group-level, organization-level, and society-level OCBs were 0.846, 0.933, 0.917, and 0.920 , respectively. The Cronbach alpha estimate was 0.964 for overall OCB scale.

\subsubsection{Control Variables}

Previous research illustrated the significant effects of personal characteristics, such as marital status, age, educational level, years of service, and monthly income on OCB [33,41,76-78]. Therefore, we controlled for the demographics of physical health status, marital status, age, educational level, job tenure, and monthly income. Among the 700 valid respondents, $65.7 \%$ were in good health or better, $94.3 \%$ were married, $32.6 \%$ were between 18 and 36 years old, $79.7 \%$ had junior high school education or lower, and $59.1 \%$ had $3-9$ years of service. Furthermore, $80.9 \%$ of participants' monthly incomes were between 468 and -780 dollars.

\subsection{Data Analysis}

A series of hierarchical regression analyses were performed to test hypotheses. Following suggestions of Preacher and Hayes [80], two analytical approaches were used to analyze the mediating effect. First, the standard Baron and Kenny [81] procedures were adopted. In this approach, the hypothesized $\mathrm{X} \rightarrow \mathrm{M} \rightarrow \mathrm{Y}$ model is considered to be supported if $\mathrm{X}$ (independent variable) has 
significant effects on $\mathrm{M}$ (mediator) and $\mathrm{Y}$ (dependent variable), and $\mathrm{M}$ has a significant effect on $\mathrm{Y}$ after accounting for $X$. The mediating effect is considered to be supported when the impact of $X$ on $Y$ is reduced with both $\mathrm{X}$ and $\mathrm{M}$ included in the same regression equation predicting $\mathrm{Y}$. Second, we used Hayes' PROCESS program to perform bootstrap sampling (bootstrap sample size $=5000$ ) to examine the significance of the indirect effect of performance appraisal purpose on OCB and its four dimensions through organizational identification. When $95 \% \mathrm{CI}$ of the indirect effect did not contain zero, it is considered that mediating effects of variables were significant. When compared to the traditional test methods, such as the Sobel test, bootstrap sampling can produce a more accurate estimate of the indirect effect [82], and thus is widely used in many fields.

\section{Results}

\subsection{Descriptive Statistics}

The descriptive statistics and correlations for all variables are shown in Table 1 . The mean value of developmental purpose of the performance appraisal $(\overline{\mathrm{u}}=3.45)$ was 0.54 points higher than that of evaluative purpose of the performance appraisal $(\overline{\mathrm{u}}=2.91)$. These results indicated that coal mining enterprises not only take performance appraisal results as an important basis for making such decisions as allocation rewards, salary increases, and job promotions, but also pay more attention to using performance appraisal results to help miners identify their strengths and weaknesses and improve their ability. The mean value of organizational identification was 3.74 , indicating that miners in coal mining enterprises have a high level of organizational identification. In addition, the mean value of overall OCB was 3.90. Among the four dimensions, the mean value of individual-level OCB was the lowest $(\overline{\mathrm{u}}=3.63)$, and that for group-level OCB was the highest $(\overline{\mathrm{u}}=4.02)$. These results showed that miners in coal mining enterprises are relatively more likely to perform group-level OCB such as helping coworkers, and less likely to conduct individual-level OCB such as self-learning. This outcome is consistent with research of Rhee et al. [83], and in line with the Chinese-specific cultural context in which employees in enterprises of China attach importance to interpersonal relationships.

Table 1. Descriptive statistics: Means, SD and correlations among study variables.

\begin{tabular}{lcccccccccc}
\hline \multicolumn{1}{c}{ Variable } & $\overline{\mathbf{u}}$ & SD & $\mathbf{1}$ & $\mathbf{2}$ & $\mathbf{3}$ & $\mathbf{4}$ & $\mathbf{5}$ & $\mathbf{6}$ & $\mathbf{7}$ & $\mathbf{8}$ \\
\hline 1. DPA & 3.45 & 0.89 & 1 & & & & & & \\
2. EPA & 2.91 & 1.20 & $0.21^{* *}$ & 1 & & & & & \\
3. OCB & 3.90 & 0.76 & $0.46^{* *}$ & $0.18^{* *}$ & 1 & & & & \\
4. OCB-I & 3.63 & 0.89 & $0.43^{* *}$ & $0.21^{* *}$ & $0.83^{* *}$ & 1 & & & \\
5. OCB-G & 4.02 & 0.80 & $0.42^{* *}$ & $0.15^{* *}$ & $0.93^{* *}$ & $0.67^{* *}$ & 1 & & \\
6. OCB-O & 3.98 & 0.85 & $0.42^{* *}$ & $0.13^{* *}$ & $0.92^{* *}$ & $0.65^{* *}$ & $0.84^{* *}$ & 1 & & \\
7. OCB-S & 3.99 & 0.92 & $0.38^{* *}$ & $0.14^{* *}$ & $0.86^{* *}$ & $0.59^{* *}$ & $0.76^{* *}$ & $0.81^{* *}$ & 1 & \\
8. OID & 3.74 & 0.86 & $0.53^{* *}$ & $0.18^{* *}$ & $0.60^{* *}$ & $0.53^{* *}$ & $0.55^{* *}$ & $0.53^{* *}$ & $0.50^{* *}$ & 1 \\
\hline
\end{tabular}

Note: $N=700 ; * * p<0.01, * p<0.05 ; \overline{\mathrm{u}}=$ means, $\mathrm{SD}=$ standard deviations. DPA = Developmental purpose of the performance appraisal, EPA = Evaluative purpose of the performance appraisal; $\mathrm{OCB}=$ Organizational citizenship behavior; OID = Organizational identification. Variables No. 4-7 indicate sub-scales of organizational citizenship behavior: OCB-I = Individual-level organizational citizenship behavior, OCB-G = Group-level organizational citizenship behavior, OCB-O = Organizational-level organizational citizenship behavior, OCB-S = Society-level organizational citizenship behavior.

\subsection{Regression Analysis}

The regression results from models M1-M27 testing our hypotheses are reported in Tables 2-4 by adding control variables (physical health status, marital status, age, educational level, years of service and monthly income), independent variables (developmental purpose of the performance appraisal and evaluative purpose of the performance appraisal), and mediator variables (organizational identification). 
Table 2. Regression results for performance appraisal purpose on organizational identification (OID) and organizational citizenship behavior (OCB).

\begin{tabular}{|c|c|c|c|c|c|c|c|}
\hline & \multicolumn{2}{|c|}{ OID } & \multicolumn{5}{|c|}{ OCB } \\
\hline & M1 & M2 & M3 & M4 & M5 & M6 & M7 \\
\hline Health & 0.04 & 0.07 & 0.04 & 0.05 & 0.03 & 0.08 * & 0.04 \\
\hline Marriage & -0.00 & -0.02 & -0.03 & -0.03 & -0.03 & -0.04 & -0.03 \\
\hline Age & 0.02 & 0.03 & 0.02 & 0.03 & 0.02 & 0.04 & 0.03 \\
\hline Education & 0.04 & 0.06 & 0.01 & 0.04 & 0.02 & 0.05 & 0.02 \\
\hline Tenure & -0.02 & -0.04 & -0.03 & -0.03 & -0.02 & -0.05 & -0.03 \\
\hline Income & 0.03 & 0.06 & $0.10^{* *}$ & $0.11^{* *}$ & $0.10^{* *}$ & $0.14^{* *}$ & $0.10^{* *}$ \\
\hline DPA & $0.53 * *$ & & & $0.45^{* *}$ & $0.20^{* *}$ & & \\
\hline EPA & & $0.18^{* *}$ & & & & $0.17^{* *}$ & $0.07^{* *}$ \\
\hline OID & & & $0.58^{* *}$ & & $0.48^{* *}$ & & $0.57^{* *}$ \\
\hline $\mathrm{R}^{2}$ & & & & 0.24 & 0.40 & 0.07 & 0.38 \\
\hline$\Delta \mathrm{R}^{2}$ & & & & & 0.16 & & 0.31 \\
\hline $\mathrm{F}$ & & & & 30.70 & 57.30 & 6.836 & 51.69 \\
\hline
\end{tabular}

Note: $N=700 . \mathrm{M} 1-\mathrm{M} 7=$ regression models $1-7 ;{ }^{* *} p<0.01,{ }^{*} p<0.05$. DPA $=$ Developmental purpose of the performance appraisal, $\mathrm{EPA}=$ Evaluative purpose of the performance appraisal; $\mathrm{OCB}=$ Organizational citizenship behavior; OID = Organizational identification. $\mathrm{R}^{2}=$ Coefficient of determination, it represents the degree of interpretation of the variable $\mathrm{X}$ for $\mathrm{Y}$ in the equation; $\Delta \mathrm{R}^{2}$ represents the changes in the degree of interpretation of the variable $\mathrm{X}$ for $\mathrm{Y}$ in the equation; $\mathrm{F}$ represents that he linear relationship of the regression equation is significant.

Table 3. Regression results for performance appraisal purpose and organizational identification (OID) on individual-level organizational citizenship behavior (OCB-I) and group-level OCB (OCB-G).

\begin{tabular}{ccccccccccc}
\hline & \multicolumn{9}{c}{ OCB-I } & \multicolumn{7}{c}{ OCB-G } \\
\cline { 2 - 11 } & M8 & M9 & M10 & M11 & M12 & M13 & M14 & M15 & M16 & M17 \\
\hline Health & 0.05 & 0.06 & 0.05 & $0.09^{*}$ & 0.05 & -0.01 & 0.00 & -0.01 & 0.03 & -0.01 \\
Marriage & -0.04 & -0.04 & -0.04 & -0.05 & -0.04 & -0.02 & -0.02 & -0.02 & -0.03 & -0.02 \\
Age & -0.01 & 0.00 & 0.00 & 0.02 & 0.00 & 0.00 & 0.01 & 0.00 & 0.01 & 0.00 \\
Education & 0.03 & 0.05 & 0.03 & 0.06 & 0.04 & 0.00 & 0.02 & 0.00 & 0.04 & 0.01 \\
Tenure & -0.06 & -0.06 & -0.05 & -0.08 & -0.06 & -0.03 & -0.04 & -0.03 & -0.06 & -0.03 \\
Income & $0.10^{* *}$ & $0.11^{* *}$ & $0.09^{* *}$ & $0.12^{* *}$ & $0.09^{* *}$ & $0.10^{* *}$ & $0.11^{* *}$ & $0.10^{* *}$ & $0.13^{* *}$ & $0.10^{* *}$ \\
DPA & & $0.41^{* *}$ & $0.20^{* *}$ & & & & $0.41^{* *}$ & $0.17^{*}$ & & \\
EPA & & & & $0.21^{* *}$ & $0.12^{* *}$ & & & & $0.14^{* *}$ & 0.05 \\
OID & $0.51^{* *}$ & & $0.41^{* *}$ & & $0.49^{* *}$ & $0.54 * *$ & & $0.45^{* *}$ & & $0.54^{* *}$ \\
$\mathrm{R}^{2}$ & & 0.21 & 0.33 & 0.08 & 0.31 & & 0.19 & 0.34 & 0.05 & 0.32 \\
$\mathrm{R}^{2}$ & & & 0.12 & & 0.23 & & & 0.15 & & 0.27 \\
$\mathrm{~F}$ & & 25.654 & 41.817 & 8.782 & 39.242 & & 23.151 & 43.806 & 4.692 & 40.249 \\
\hline
\end{tabular}

Note. $N=700$. M8-M17 $=$ regression models $8-17 ;{ }^{* *} p<0.01,{ }^{*} p<0.05$. DPA $=$ Developmental purpose of the performance appraisal; EPA = Evaluative purpose of the performance appraisal; OID = Organizational identification; OCB-I = Individual-level organizational citizenship behavior, OCB-G = Group-level organizational citizenship behavior. $R^{2}=$ Coefficient of determination, it represents the degree of interpretation of the variable $\mathrm{X}$ for $\mathrm{Y}$ in the equation; $\Delta R^{2}$ represents the changes in the degree of interpretation of the variable $X$ for $Y$ in the equation; $\mathrm{F}$ represents that he linear relationship of the regression equation is significant.

Table 4. Regression results for performance appraisal purpose and organizational identification (OID) on organizational-level organizational citizenship behavior (OCB-O) and society-level OCB (OCB-S).

\begin{tabular}{|c|c|c|c|c|c|c|c|c|c|c|}
\hline & \multicolumn{5}{|c|}{ OCB-O } & \multicolumn{5}{|c|}{ OCB-S } \\
\hline & M18 & M19 & M20 & M21 & M22 & M23 & M24 & M25 & M26 & M27 \\
\hline Health & 0.04 & 0.05 & 0.03 & 0.07 & 0.04 & 0.06 & 0.07 & 0.05 & $0.09^{*}$ & 0.06 \\
\hline Marriage & -0.03 & -0.03 & -0.03 & -0.04 & -0.03 & -0.02 & -0.02 & -0.02 & -0.03 & -0.02 \\
\hline Age & 0.05 & 0.06 & 0.05 & 0.07 & 0.05 & $0.05^{*}$ & 0.05 & 0.05 & 0.06 & 0.05 \\
\hline Education & 0.03 & 0.05 & 0.03 & 0.06 & 0.03 & -0.01 & 0.01 & -0.01 & 0.02 & 0.00 \\
\hline Tenure & -0.01 & -0.01 & 0.00 & -0.03 & -0.01 & 0.01 & 0.01 & 0.01 & -0.01 & 0.01 \\
\hline Income & $0.08^{*}$ & $0.09 *$ & $0.08^{*}$ & $0.11^{* *}$ & $0.08 *$ & $0.08^{*}$ & $0.09 *$ & $0.07 *$ & $0.10^{* *}$ & $0.08 *$ \\
\hline DPA & & $0.41^{* *}$ & $0.20^{* *}$ & & & & $0.37^{* *}$ & $0.15^{* *}$ & & \\
\hline EPA & & & & $0.12 * *$ & 0.03 & & & & $0.14^{* *}$ & 0.05 \\
\hline OID & $0.52^{* *}$ & & $0.41^{* *}$ & & $0.51^{* * *}$ & $0.49^{* *}$ & & $0.41^{* *}$ & & $0.48^{* *}$ \\
\hline $\mathrm{R}^{2}$ & & 0.20 & 0.32 & 0.04 & 0.29 & & 0.16 & 0.28 & 0.05 & 0.27 \\
\hline$\Delta \mathrm{R}^{2}$ & & & 0.12 & & 0.25 & & & 0.12 & & 0.22 \\
\hline $\mathrm{F}$ & & 24.152 & 39.936 & 4.405 & 35.112 & & 18.791 & 33.704 & 4.609 & 31.402 \\
\hline
\end{tabular}

Note: $N=700$. M18-M27 = regression models $18-27 ;{ }^{* *} p<0.01,{ }^{*} p<0.05$. DPA = Developmental purpose of the performance appraisal; EPA = Evaluative purpose of the performance appraisal; OID = Organizational identification; OCB-O = Organizational-level organizational citizenship behavior, OCB-S = Society-level organizational citizenship behavior. $R^{2}=$ Coefficient of determination, it represents the degree of interpretation of the variable $X$ for $Y$ in the equation; $\Delta \mathrm{R}^{2}$ represents the changes in the degree of interpretation of the variable $\mathrm{X}$ for $\mathrm{Y}$ in the equation; $\mathrm{F}$ represents that he linear relationship of the regression equation is significant. 
As the results shown in Tables 2-4, both developmental purpose of the performance appraisal and organizational identification had positive and significant effects on overall $O C B$, individual-level $O C B$, group-level OCB, organization-level OCB, and society-level OCB, respectively). Thus, Hypothesis 1a was supported. Model M1 (Table 1) showed a positive relationship between developmental purpose of the performance appraisal and organizational identification, therefore Hypothesis 2a was supported. Even after taking organizational identification into account, the positive effects of developmental purpose of the performance appraisal on overall OCB, individual-level OCB, group-level OCB, organization-level OCB, and society-level OCB were still significant (but reduced).

In addition, as the results shown in Tables $2-4$, the bootstrapping test indicated that the indirect effects of developmental purpose of the performance appraisal on overall OCB (i.e., indirect effect $=0.2184,95 \%$ confidence interval $(C I)=[0.1652,0.2781]$ ), individual-level OCB (i.e., indirect effect $=0.2201,95 \% \mathrm{CI}=[0.1611,0.2890])$, group-level $\mathrm{OCB}$ (i.e., indirect effect $=0.2183$, $95 \% \mathrm{CI}=[0.1617,0.2825])$, organization-level OCB (i.e., indirect effect $=0.2100,95 \% \mathrm{CI}=[0.1545$, $0.2762]$ ), and society-level OCB (i.e., indirect effect $=0.2285,95 \% \mathrm{CI}=[0.1664,0.3003]$ ) via organizational identification were significant, because the $95 \%$ CI of the indirect effect did not contain zero. Therefore, organizational identification partially mediated the effects of developmental purpose of the performance appraisal on overall OCB and its four dimensions, and Hypothesis $2 b$ was supported.

Evaluative purpose of the performance appraisal had positive and significant effects on organizational identification, overall $\mathrm{OCB}$, individual-level $\mathrm{OCB}$, group-level $\mathrm{OCB}$, organization-level OCB and society-level OCB. Thus, Hypotheses $1 \mathrm{~b}$ and $3 \mathrm{a}$ were refused. The positive effects of evaluative purpose of the performance appraisal on overall OCB and individual-level OCB were significant (and reduced) after taking organizational identification into account. However, after taking organizational identification into account the positive effects of evaluative purpose of the performance appraisal on group-level OCB, organization-level OCB, and society-level OCB were nonsignificant.

In addition, the bootstrapping test indicated that the indirect effects of evaluative purpose of the performance appraisal on overall OCB (i.e., indirect effect $=0.0651,95 \% \mathrm{CI}=[0.0347,0.0973]$ ), individual-level OCB (i.e., indirect effect $=0.0657,95 \% \mathrm{CI}=[0.0364,0.1015]$ ), group-level $\mathrm{OCB}$ (i.e., indirect effect $=0.0641,95 \% \mathrm{CI}=[0.0354,0.0956]$ ), organization-level OCB (i.e., indirect effect $=0.0648,95 \% \mathrm{CI}=[0.0357,0.0992]$ ), $\quad$ and society-level $\mathrm{OCB}$ (i.e., indirect effect $=0.0667,95 \% \mathrm{CI}=[0.0371,0.1001]$ ) $\quad$ via organizational identification were significant because the $95 \% \mathrm{CI}$ of the indirect effects did not contain zero. Therefore, organizational identification partially mediated the effects of evaluative purpose of the performance appraisal on overall OCB and individual-level OCB, and completely mediated the effects of evaluative purpose of the performance appraisal on group-level, organization-level and society-level OCB. Thus Hypothesis $3 \mathrm{~b}$ was supported.

It is worth noting that income is positively correlated with overall OCB and its four dimensions. It may be that as incomes increase, people perceive an increase in feedback from the organization. According to the theory of social exchange, employees also reward the organization by adopting extra-role behaviors such as OCB.

\section{Discussion}

\subsection{The Relationship between Performance Appraisal Purpose and OCB}

The results verified a positive relationship between developmental purpose of the performance appraisal and overall OCB and its four dimensions. A possible reason for this outcome may be that developmental purpose of the performance appraisals apply an individual's appraisal results to help miners identify their own strengths and weaknesses and improve their working ability. These improvements are essential for works in coal mine industry since it's work condition is more dangerous compared with other industries. In so doing, career development demands related to personal skill promotion of miners are satisfied, and demands for intrinsic values such as promotion of 
personal skills and career development are validated, which is consistent with the study of Han et al. who investigate three large state-owned coal mining groups in China [84]. According to social exchange theory, when one party helps or benefits another party, there is an expectation of a future repayment that meets the supplier's requirements. Similarly, when miners perceive organizational support and organizational investment in themselves, they tend to give more positive feedback to the organization, such as more OCB.

Our study found that evaluative purpose of the performance appraisal can positively promote the overall OCB and its four dimensions. The reason for this finding may be attributed to the fact that in the Chinese native cultural context, appraisers tend to have cognitive biases when evaluating miners' performance [85]. In addition to objective performance indicators, contextual performance is also an important criterion and metric when appraisers evaluate employees [86]. Similarly, OCB such as saving organizational resources can significantly improve the contextual performance of an organization [87], and further affect the results of miners' performance appraisal. Therefore, with the aim to present a "good soldier" image in front of the leaders [86], miners will adopt various impression management strategies to actively present false OCB and exert influence on the appraiser's judgment of their behavior [88], thereby further improving their performance appraisal level to gain rewards and avoid punishments.

According to the findings of this study, the impact of developmental purpose of the performance appraisal on overall OCB and its dimensions is significantly stronger than that of evaluative purpose of the performance appraisal. This shows that although miners in coal mining enterprises pay attention to extrinsic rewards such as salary and welfare; however, they may be more concerned about the improvement of vocational skills and the prospect of career development. Compared with short-term and results-oriented evaluative purpose of the performance appraisal, long-term oriented developmental purpose of the performance appraisal will pay more attention to the results of the appraisal as a tool to help miners identify their own strengths and weaknesses, and improve occupational skills. Thus, developmental purpose of the performance appraisal will be more able to meet the miners' needs for skills promotion and career development and promote their motivation.

\subsection{The Mediating Effects of Organizational Identification}

Our study confirms that organizational identification has a partial mediating effect on the relationship between developmental purpose of the performance appraisal and overall OCB and its four dimensions. This finding suggests that, because developmental purpose of the performance appraisal meets miners' needs for self-development such as skills promotion and career development, miners are more likely to perceive support and help from organizations that use this type of appraisal. The perceived support will enhance miners' organizational identification and further encourage miners to perform OCB to achieve organizational success.

Our study also found that organizational identification has a mediating effect on the relationship between the evaluative purpose of the performance appraisal and overall OCB and its four dimensions. This finding suggests that when the evaluative purpose of the performance appraisal is used to reward or punish miners according to their appraisal results, miners will perceive that their own individual efforts get fair and reasonable recognition and repayments from the organization. This perception will motivate miners' initiative for work and enhance their organizational identification. Consequently, miners would like to actively undertake OCB to improve personal performance and contextual performance in order to get more organizational rewards and avoid punishment.

\section{Implications for Research and Practice, Limitations, and Future Research}

Our study mainly makes a theoretical contribution to the following two aspects of OCB research. First, it explores the effects of two kinds of performance appraisal purposes on miners' OCB. On the one hand, our study innovatively advances safety behavior management research in the coal mining industry by exploring the regularity characteristics of the miners' active safety behaviors from the 
perspective of effects of performance appraisal purposes on OCB. On the other hand, our study verifies the importance of human resources management practices to safety management of coal mining enterprises, and calls for transition from the previously used extensive and mandatory management approaches to people-oriented human resources management in coal mining enterprises. This finding further improves safety management theory and practice. Second, our research investigated the mediating effect of organizational identification on the relationship between performance appraisal purposes and OCB. By contradicting the "economic man" hypothesis proposed in previous studies (i.e., the idea that employees are concerned only with welfare and salary), our research proved that human resource management practice in coal mining enterprises affects the degree of "emotional binding" between miners and coal mining enterprises [89] and further affects miners' positive OCB.

Conclusions from this study are of great practical significance in motivating miners' OCB in coal mining enterprises from the perspective of performance appraisal practice. First, we found that both developmental purpose of the performance appraisal and evaluative purpose of the performance appraisal have positive effects on OCB. Therefore, the performance appraisal of coal mining enterprises should focus on both "development" and "evaluation", and subsequently promote miners' organizational identification and OCB. Additionally, developmental purpose of the performance appraisal can improve miners' OCB better than evaluative purpose of the performance appraisal; thus, performance appraisal results are not only useful as a basis for salary and promotion, but also relate to miners' skills improvement and career development. On the one hand, performance appraisal should take specific needs of miners in different positions into account, and emphasize and distinguish differences in the contents and methods of performance appraisal. Additionally, targeted training guidance for miners should be provided according to their required skills. On the other hand, to the extent possible, performance appraisal should provide services such as self-assessment opportunities and career development planning consultation for miners in different stages of their careers. In so doing, miners' OCB can be promoted effectively.

Second, organizational identification among miners is not only affected by performance appraisal purposes, but also has a significant and positive impact on the miners' OCB. Accordingly, coal mining enterprises should pay attention to the key role of organizational identification in promoting OCB of miners. In the same situation of performance appraisal practice, differences in needs of individual miners could lead to differences in the degree of miners' organizational identification to a coal mining enterprise. Thus, it is essential that the design of a performance appraisal system in a coal mining enterprise should consider the miners' different characteristics because these differences may affect the relationship between two kinds of performance appraisal purposes and organizational identification. Enterprises should thus implement differentiated management strategies for miners with different needs. For those miners who pay more attention to salary and welfare, coal mining enterprises should perfect the compensation and welfare system as much as possible and cultivate miners' organizational identification on the basis of meeting their material needs so as to stimulate them to perform more OCB. For miners who value self-development more than extrinsic rewards, coal mining enterprises should provide more organizational support and resources to help miners' promote their occupational skills and career advancement in order to enhance their organizational identification and subsequently stimulate their OCB.

Despite the innovative nature and significance of our research, it has some limitations. First, all survey respondents were front-line miners and foremen; we ignored middle and senior managers. Future research can increase the breadth of the respondent sample population to include middle and senior managers, and compare differences in the relationships between performance appraisal purposes and OCB for employees at different levels of management. Second, "common method bias" is a potential source of error because our data were collected from a single source at one time. However, both performance appraisal purposes and organizational identification belong to psychological variables of miners that can be accurately measured by self-reporting methods. As for $\mathrm{OCB}$, few differences in results between self-appraisal and independent appraisal have been 
measured according to the meta-analysis of Carpenter, Berry, and Houston [90]. Nevertheless, future research should adopt independent appraisal or objective measures to reduce the impact of common method bias. Finally, the data used in this research were collected from employees in coal mining enterprises; thus our research may have a certain bias, therefore, future research should add Thompson's long-linked technology [91] to avoid such problems.

\section{Conclusions}

This research used questionnaires and empirical analysis to explore the relationship between performance appraisal purposes and OCB as well as the mediating role of organizational identification of front-line miners in Chinese coal mining enterprises. The conclusions are as follows.

(1) Both development performance appraisal and evaluative purpose of the performance appraisal significantly and positively affect overall OCB and its four dimensions. However, compared with evaluative purpose of the performance appraisal, developmental purpose of the performance appraisal has a stronger impact on overall OCB and its four dimensions. This finding indicates that miners will be motivated to perform more OCB when coal mining enterprises use performance appraisal results to help miners improve their occupational ability and promote career development.

(2) Both development performance appraisal and evaluative purpose of the performance appraisal significantly and positively affect organizational identification. In addition, compared with evaluative purpose of the performance appraisal, developmental purpose of the performance appraisal has a stronger impact on organizational identification. Because miners in coal mining enterprises pay more attention to intrinsic demands such as skill upgrading than to extrinsic demands such as salary and welfare, developmental purpose of the performance appraisal is more able to meet intrinsic demands of miners compared with evaluative purpose of the performance appraisal. Consequently, developmental purpose of the performance appraisal is more likely than evaluative purpose of the performance appraisal to enhance organizational identification.

(3) Organizational identification has significant and positive impacts on OCB and its four dimensions. Higher organizational identification can effectively enhance miners' sense of responsibility for maintaining organizational interests, which motivates miners to perform more OCB.

(4) Organizational identification partially mediates the effects of developmental purpose of the performance appraisal on overall OCB, as well as on individual-level, group-level, organization-level, and society-level OCB. Organizational identification partially mediates the effects of evaluative purpose of the performance appraisal on overall OCB and individual-level $\mathrm{OCB}$, and completely mediates the effects of evaluative purpose of the performance appraisal on group-level, organization-level, and society-level OCB. These conclusions show that organizational identification is one of the key variables that connects miners' performance appraisal purposes and OCB.

Author Contributions: H.L. came up with the original ideas and wrote the paper, A.Y. collected the data and wrote the paper, H.Y. contributed to the translation of the paper, and H.C. gave some advice on the paper and contributed to the writing of the paper. H.L. and H.C. are the corresponding authors of the paper and H.L. and A.Y. contributed equally to this work. All authors read and approved this version.

Funding: This research was funded by the National Natural Science Foundation of China Project (grant Nos. 71603255, 71673271), the Major Project of the National Social Science Foundation of China (grant No. 16ZDA056), Qing Lan Project of Jiangsu Province (2018), the "13th Five Year" brand discipline specialty building project of China University of Mining and Technology (2017), the "13th Five Year" Brand Discipline Construction Funding Project of China University of Mining and Technology (2017), the Fundamental Research Funds for the Central Universities (grant No. 2017WB16), and the Think Tank of Green Safety Management and Policy Science (2018 "Double First-Class" Initiative Project for Cultural Evolution and Creation of CUMT 2018WHCC03). and The APC was funded by the National Natural Science Foundation of China Project (grant Nos. 71603255, 71673271) and the Think Tank of Green Safety Management and Policy Science (2018 “Double First-Class" Initiative Project for Cultural Evolution and Creation of CUMT 2018WHCC03).

Conflicts of Interest: The authors declare no conflicts of interest. 


\section{References}

1. State Administration of Coal Mine Safety of China. National Conference on Production Safety. 2017. Available online: http:/ /www.chinasafety.gov.cn/newpage/Contents/Channel_22240/2017/0116/282416/ content_282416.htm (accessed on 12 March 2018).

2. State Administration of Coal Mine Safety of China. 2017. Available online: http://www.chinasafety.gov.cn/ newpage/Contents /Channel_22249/2017/0317/284828/content_284828.htm (accessed on 12 March 2018).

3. Yin, W.; Fu, G.; Yang, C.; Jiang, Z.; Zhu, K.; Gao, Y. Fatal gas explosion accidents on Chinese coal mines and the characteristics of unsafe behaviors: 2000-2014. Saf. Sci. 2017, 92, 173-179. [CrossRef]

4. Chen, H.; Qi, H.; Long, R.; Zhang, M. Research on 10-year tendency of china coal mine accidents and the characteristics of human factors. Saf. Sci. 2012, 50, 745-750. [CrossRef]

5. Zhao, X.; Ma, S. Application of Man-Machine-Environment System Engineering in Coal Mine Accident. In Man-Machine-Environment System Engineering; Springer: Singapore, 2016; pp. 601-608.

6. Chen, H.; Qi, H.; Feng, Q. Characteristics of direct causes and human factors in major gas explosion accidents in Chinese coal mines: Case study spanning the years 1980-2010. J. Loss Prev. Process Ind. 2013, 26, 38-44. [CrossRef]

7. Treviño, L.K.; den Nieuwenboer, N.A.; Kishgephart, J.J. (un)ethical behavior in organizations. Annu. Rev. Psychol. 2014, 65, 635. [CrossRef] [PubMed]

8. Paul, P.S.; Maiti, J. The role of behavioral factors on safety management in underground mines. Saf. Sci. 2007, 45, 449-471. [CrossRef]

9. Organ, D.W. Organizational Citizenship Behavior: The Good Soldier Syndrome; Lexington Books: Lexington, KY, USA, 1988; p. 56.

10. Organ, D.W. Organizational citizenship behavior: It's construct clean-up time. Hum. Perform. 1997, 10, 85-97. [CrossRef]

11. Organ, D.W.; Podsakoff, P.M.; MacKenzie, S.B. Organizational Citizenship Behavior: Its Nature, Antecedents, and Consequences; Sage Publications: Thousand Oaks, CA, USA, 2005.

12. Shahin, A.; Shabani Naftchali, J.; Khazaei Pool, J. Developing a model for the influence of perceived organizational climate on organizational citizenship behavior and organizational performance based on balanced score card. Int. J. Prod. Perform. Manag. 2014, 63, 290-307. [CrossRef]

13. Ng, T.W.H.; Feldman, D.C. Affective organizational commitment and citizenship behavior: Linear and non-linear moderating effects of organizational tenure. J. Vocat. Behav. 2011, 79, 528-537. [CrossRef]

14. Curcuruto, M.; Conchie, S.M.; Mariani, M.G.; Violante, F.S. The role of prosocial and proactive safety behaviors in predicting safety performance. Saf. Sci. 2015, 80, 317-323. [CrossRef]

15. Mostafa, A.M.S.; Gould-Williams, J.S. Testing the mediation effect of person-organization fit on the relationship between high performance HR practices and employee outcomes in the Egyptian public sector. Int. J. Hum. Resour. Manag. 2014, 25, 276-292. [CrossRef]

16. Kehoe, R.R.; Wright, P.M. The impact of high-performance human resource practices on employees' attitudes and behaviors. J. Manag. 2013, 39, 366-391. [CrossRef]

17. Mostafa, A.M.S.; Gould-Williams, J.S.; Bottomley, P. High-performance human resource practices and employee outcomes: The mediating role of public service motivation. Public Adm. Rev. 2015, 75, 747-757. [CrossRef]

18. Alfes, K.; Shantz, A.D.; Truss, C.; Soane, E.C. The link between perceived human resource management practices, engagement and employee behaviour: A moderated mediation model. Int. J. Hum. Resour. Manag. 2013, 24, 330-351. [CrossRef]

19. Cleveland, J.N.; Murphy, K.R.; Williams, R.E. Multiple uses of performance appraisal: Prevalence and correlates. J. Appl. Psychol. 1989, 74, 130-135. [CrossRef]

20. Jiang, J.; Wang, S.; Zhao, S. Does HRM facilitate employee creativity and organizational innovation? A study of Chinese firms. Int. J. Hum. Resour. Manag. 2012, 23, 4025-4047. [CrossRef]

21. Boswell, W.R.; Boudreau, J.W. Employee satisfaction with performance appraisals and appraisers: The role of perceived appraisal use. Hum. Resour. Dev. Q. 2000, 11, 283. [CrossRef]

22. Poursafar, A.; Rajaeepour, S.; Seyadat, S.A.; Oreizi, H.R. Developmental performance appraisal and organizational citizenship behavior: Testing a mediation model. J. Educ. Pract. 2014, 5, 184-193. 
23. Taylor, P.J.; Pierce, J.L. Effects of introducing a performance management system on employees' subsequent attitudes and effort. Public Pers. Manag. 1999, 28, 423-452. [CrossRef]

24. Ajzen, I.; Fishbein, M. Attitude-behavior relations: A theoretical analysis and review of empirical research. Psychol. Bull. 1977, 84, 888-918. [CrossRef]

25. Tajfel, H.; Turner, J.C. The Social Identity Theory of Intergroup Behavior. In Psychology of Intergroup Relations; Worchel, S., Austin, W., Eds.; Nelson Hall: Chicago, IL, USA, 1986.

26. Sun, L.Y.; Aryee, S.; Law, K.S. High-performance human resource practices, citizenship behavior, and organizational performance: A relational perspective. Acad. Manag. J. 2007, 50, 558-577. [CrossRef]

27. Foreman, P.; Whetten, D.A. Members' identification with multiple-identity organizations. Organ. Sci. 2002, 13, 618-635. [CrossRef]

28. Shin, Y.; Kim, M.S.; Choi, J.N.; Kim, M.; Oh, W.K. Does leader-follower regulatory fit matter? The role of regulatory fit in followers' organizational citizenship behavior. J. Manag. 2017, 43, 1211-1233. [CrossRef]

29. Lam, C.F.; Liang, J.; Ashford, S.J.; Lee, C. Job insecurity and organizational citizenship behavior: Exploring curvilinear and moderated relationships. J. Appl. Psychol. 2015, 100, 499. [CrossRef] [PubMed]

30. Yang, L.Q.; Simon, L.S.; Wang, L.; Zheng, X. To branch out or stay focused? Affective shifts differentially predict organizational citizenship behavior and task performance. J. Appl. Psychol. 2016, 101, 831. [CrossRef] [PubMed]

31. Nasra, M.A.; Heilbrunn, S. Transformational leadership and organizational citizenship behavior in the Arab educational system in Israel: The impact of trust and job satisfaction. Educ. Manag. Adm. Leadersh. 2016, 44, 380-396. [CrossRef]

32. Tremblay, M.; Simard, G.; Mathlouthi, W. When Positive is Better and Negative Stronger: A study of Job Satisfaction, OCB and Absenteeism. In Academy of Management Proceedings; Academy of Management: Briarcliff Manor, NY, USA, 2016; Volume 2016, p. 10082.

33. Williams, L.J.; Anderson, S.E. Job satisfaction and organizational commitment as predictors of organizational citizenship and in-role behaviors. J. Manag. 1991, 17, 601-617. [CrossRef]

34. Tziner, A.; Sharoni, G. Organizational citizenship behavior, organizational justice, job stress, and workfamily conflict: Examination of their interrelationships with respondents from a non-Western culture. Rev. Psicol. Trab. Organ. 2014, 30, 35-42. [CrossRef]

35. Stynen, D.; Forrier, A.; Sels, L.; De Witte, H. The relationship between qualitative job insecurity and OCB: Differences across age groups. Econ. Ind. Democr. 2015, 36, 383-405. [CrossRef]

36. Chahal, H.; Mehta, S. Antecedents and consequences of organisational citizenship behaviour (OCB): A conceptual framework in reference to health care sector. J. Serv. Res. 2010, $10,25$.

37. Podsakoff, P.M.; MacKenzie, S.B.; Paine, J.B.; Bachrach, D.G. Organizational citizenship behaviors: A critical review of the theoretical and empirical literature and suggestions for future research. J. Manag. 2000, 26, 513-563. [CrossRef]

38. Mitonga-Monga, J.; Flotman, A.; Cilliers, F.V.N. Organizational citizenship behaviour among railway employees in a developing country: Effects of age, education and tenure. South. Afr. Bus. Rev. 2017, 21, 385-406.

39. Todd, S.Y.; Kent, A. Direct and Indirect Effects of Task Characteristics on Organizational Citizenship Behavior. N. Am. J. Psychol. 2006, 8, 253-268.

40. Krishnan, R.; Ismail, S.; Loon, K.W.; Muthusamy, G.; Melaka, K.B. The Moderating Effect of Employee Personality in the Relationship Between Job Design Characteristics and Organizational Citizenship Behavior. Soc. Sci. 2017, 12, 1014-1023.

41. Farh, J.L.; Zhong, C.B.; Organ, D.W. Organizational citizenship behavior in the People's Republic of China. Organ. Sci. 2004, 15, 241-253. [CrossRef]

42. Somech, A.; Ron, I. Promoting organizational citizenship behavior in schools: The impact of individual and organizational characteristics. Educ. Adm. Q. 2007, 43, 38-66. [CrossRef]

43. Lee, U.H.; Kim, H.K.; Kim, Y.H. Determinants of organizational citizenship behavior and its outcomes. Glob. Bus. Manag. Res. 2013, 5, 54.

44. Friesen, J.P.; Kay, A.C.; Eibach, R.P.; Galinsky, A.D. Seeking structure in social organization: Compensatory control and the psychological advantages of hierarchy. J. Personal. Soc. Psychol. 2014, 106, 590. [CrossRef] [PubMed] 
45. Wong, Y.T.; Wong, C.S.; Ngo, H.Y.; Lui, H.K. Different responses to job insecurity of Chinese workers in joint ventures and state-owned enterprises. Hum. Relat. 2005, 58, 1391-1418. [CrossRef]

46. Khalili, A.; Khalili, A. Transformational leadership and organizational citizenship behavior: The moderating role of emotional intelligence. Leadersh. Organ. Dev. J. 2017, 38, 1004-1015. [CrossRef]

47. Lian, L.K.; Tui, L.G. Leadership styles and organizational citizenship behavior: The mediating effect of subordinates' competence and downward influence tactics. J. Appl. Bus. Econ. 2012, 13, 59-96.

48. Robinson, S.L.; Morrison, E.W. Psychological contracts and OCB: The effect of unfulfilled obligations on civic virtue behavior. J. Organ. Behav. 1995, 16, 289-298. [CrossRef]

49. Li, N.W.; Huang, J.T.; Niu, L.X. Evolutionary model of miners' violation behavior based on multi-agent simulation. China Saf. Sci. J. 2013, 23, 10-15.

50. Li, F.W.; Yuan, Z.Y.; Li, Y.J. Effects of work environment stressors on coalmine employees' counter-productive work behavior and safety outcome. China Saf. Sci. J. 2012, 22, 20-26.

51. Kunar, B.M.; Bhattacherjee, A.; Chau, N. Relationships of job hazards, lack of knowledge, alcohol use, health status and risk taking behavior to work injury of coal miners: A case-control study in India. J. Occup. Health 2008, 50, 236-244. [CrossRef] [PubMed]

52. Du, X.; Zhao, X. An empirical investigation of the influence of safety climate on safety citizenship behavior in coal mine. Procedia Eng. 2011, 26, 2173-2180.

53. Haybatollahi, M.; Ayim, S.G. Organizational Citizenship Behaviour: A Cross-Cultural Comparative Study on Ghanaian and Finnish Industrial Workers. Scand. J. Organ. Psychol. 2015, 7, 19-32.

54. Boswell, W.R.; Boudreau, J.W. Separating the developmental and evaluative performance appraisal uses. J. Bus. Psychol. 2002, 16, 391-412. [CrossRef]

55. Cennamo, L.; Gardner, D. Generational differences in work values, outcomes and person-organisation values fit. J. Manag. Psychol. 2008, 23, 891-906. [CrossRef]

56. Lester, S.W.; Standifer, R.L.; Schultz, N.J.; Windsor, J.M. Actual versus perceived generational differences at work: An empirical examination. J. Leadersh. Organ. Stud. 2012, 19, 341-354. [CrossRef]

57. Bednall, T.C.; Sanders, K.; Runhaar, P. Stimulating informal learning activities through perceptions of performance appraisal quality and human resource management system strength: A two-wave study. Acad. Manag. Learn. Educ. 2014, 13, 45-61. [CrossRef]

58. Molm, L.D.; Peterson, G.; Takahashi, N. The value of exchange. Soc. Forces 2001, 80, 159-184. [CrossRef]

59. Wu, P. An empirical study of the relationship between individual-based performance appraisal and team performance. Nankai Bus. Rev. 2009, 12, 51-56.

60. Cravens, K.S.; Oliver, E.G.; Oishi, S.; Stewart, J.S. Workplace culture mediates performance appraisal effectiveness and employee outcomes: A study in a retail setting. J. Manag. Account. Res. 2015, 27, 1-34. [CrossRef]

61. Zhang, X.; Hu, B.; Qiu, M. Job satisfaction as a mediator in the relationship between performance appraisal and voice behavior. Soc. Behav. Personal. Int. J. 2014, 42, 1315-1323. [CrossRef]

62. Qiu, M.; Hu, B.; Xu, Z.; Li, Y. Employees' psychological ownership and self-efficacy as mediators between performance appraisal purpose and proactive behavior. Soc. Behav. Personal. Int. J. 2015, 43, 1101-1109. [CrossRef]

63. Chen, T.; Wu, P.; Leung, K. Individual performance appraisal and appraisee reactions to workgroups: The mediating role of goal interdependence and the moderating role of procedural justice. Pers. Rev. 2011, 40, 87-105. [CrossRef]

64. Kampkötter, P. Performance appraisals and job satisfaction. Int. J. Hum. Resour. Manag. 2017, 28, 750-774. [CrossRef]

65. Kim, T.; Holzer, M. Public employees and performance appraisal: A study of antecedents to employees' perception of the process. Rev. Public Pers. Adm. 2016, 36, 31-56. [CrossRef]

66. Lee, E.S.; Park, T.Y.; Koo, B. Identifying organizational identification as a basis for attitudes and behaviors: A meta-analytic review. Psychol. Bull. 2015, 141, 1049. [CrossRef] [PubMed]

67. Ngo, H.Y.; Loi, R.; Foley, S.; Zheng, X.; Zhang, L. Perceptions of organizational context and job attitudes: The mediating effect of organizational identification. Asia Pac. J. Manag. 2013, 30, 149-168. [CrossRef]

68. Üngüren, E.; Arslan, S.; KOÇ, T. The Effect of Fatalistic Beliefs Regarding Occupational Accidents on Job Satisfaction and Organizational Trust in Hotel Industry. Adv. Hosp. Tour. Res. 2017, 5, 23-56.

69. Lai, J.Y.; Lam, S.S.; Chow, C.W. What good soldiers are made of: The role of personality similarity. J. Manag. Psychol. 2015, 30, 1003-1018. [CrossRef] 
70. Deraman, F.; Ismail, N.; Arifin, A.I.M.; Mostafa, M.I.A. Green practices in hotel industry: Factors influencing the implementation. J. Tour. Hosp. Culin. Arts 2017, 9, 1-2.

71. Jones, D.A. Does serving the community also serve the company? Using organizational identification and social exchange theories to understand employee responses to a volunteerism programme. J. Occup. Organ. Psychol. 2010, 83, 857-878. [CrossRef]

72. Slack, R.E.; Corlett, S.; Morris, R. Exploring employee engagement with (corporate) social responsibility: A social exchange perspective on organizational participation. J. Bus. Ethics 2015, 127, 537-548. [CrossRef]

73. Teo, L.; Chan-Serafin, S. Moral foundations in organizations: Exploring the role of moral concerns and organizational identification on unethical pro-organizational behaviors. In Proceedings of the meeting of the Australia and New Zealand Academy of Management, Hobart, Australia, 4-6 December 2013.

74. Boyd, N.M.; Nowell, B. Testing a theory of sense of community and community responsibility in organizations: An empirical assessment of predictive capacity on employee well-being and organizational citizenship. J. Community Psychol. 2017, 45, 210-229. [CrossRef]

75. Farmer, S.M.; Van Dyne, L.; Kamdar, D. The contextualized self: How team-member exchange leads to coworker identification and helping OCB. J. Appl. Psychol. 2015, 100, 583. [CrossRef] [PubMed]

76. Van Dick, R.; van Knippenberg, D.; Kerschreiter, R.; Hertel, G.; Wieseke, J. Interactive effects of work group and organizational identification on job satisfaction and extra-role behavior. J. Vocat. Behav. 2008, 72, 388-399. [CrossRef]

77. Mael, F.; Ashforth, B.E. Alumni and their alma mater: A partial test of the reformulated model of organizational identification. J. Organ. Behav. 1992, 13, 103-123. [CrossRef]

78. Yoshida, D.T.; Sendjaya, S.; Hirst, G.; Cooper, B. Does servant leadership foster creativity and innovation? A multi-level mediation study of identification and prototypicality. J. Bus. Res. 2014, 67, 1395-1404. [CrossRef]

79. Loi, R.; Chan, K.W.; Lam, L.W. Leader-member exchange, organizational identification, and job satisfaction: A social identity perspective. J. Occup. Organ. Psychol. 2014, 87, 42-61. [CrossRef]

80. Preacher, K.J.; Hayes, A.F. Asymptotic and resampling strategies for assessing and comparing indirect effects in multiple mediator models. Behav. Res. Methods 2008, 40, 879-891. [CrossRef] [PubMed]

81. Baron, R.M.; Kenny, D.A. The moderator-mediator variable distinction in social psychological research: Conceptual, strategic, and statistical considerations. J. Personal. Soc. Psychol. 1986, 51, 1173. [CrossRef]

82. MacKinnon, D.P.; Lockwood, C.M.; Hoffman, J.M.; West, S.G.; Sheets, V. A comparison of methods to test mediation and other intervening variable effects. Psychol. Methods 2002, 7, 83. [CrossRef] [PubMed]

83. Rhee, J.; Zhao, X.; Jun, I.; Kim, C. Effects of collectivism on Chinese organizational citizenship behavior: Guanxi as moderator. Soc. Behav. Personal. Int. J. 2017, 45, 1127-1142. [CrossRef]

84. Han, S.; Chen, H.; Long, R.; Qi, H.; Cui, X. Evaluation of the derivative environment in coal mine safety production systems: Case study in China. J. Clean. Prod. 2017, 143, 377-387. [CrossRef]

85. Belle, N.; Cantarelli, P.; Belardinelli, P. Cognitive Biases in Performance Appraisal: Experimental Evidence on Anchoring and Halo Effects with Public Sector Managers and Employees. Rev. Public Pers. Adm. 2017, 37, 275-294. [CrossRef]

86. Methot, J.R.; Lepak, D.; Shipp, A.J.; Boswell, W.R. Good citizen interrupted: Calibrating a temporal theory of citizenship behavior. Acad. Manag. Rev. 2017, 42, 10-31. [CrossRef]

87. Bozionelos, N.; Singh, S.K. The relationship of emotional intelligence with task and contextual performance: More than it meets the linear eye. Personal. Individ. Differ. 2017, 116, 206-211. [CrossRef]

88. Bolino, M.C.; Klotz, A.C.; Turnley, W.H.; Harvey, J. Exploring the dark side of organizational citizenship behavior. J. Organ. Behav. 2013, 34, 542-559. [CrossRef]

89. Deepa, E.; Palaniswamy, R.; Kuppusamy, S. Effect of performance appraisal system in organizational commitment, job satisfaction and productivity. J. Contemp. Manag. Res. 2014, 8, 72.

90. Carpenter, N.C.; Berry, C.M.; Houston, L. A meta-analytic comparison of self-reported and other-reported organizational citizenship behavior. J. Organ. Behav. 2014, 35, 547-574. [CrossRef]

91. Thompson, J.D. Organizations in Action; McGraw-Hill: New York, NY, USA, 1967.

(C) 2018 by the authors. Licensee MDPI, Basel, Switzerland. This article is an open access article distributed under the terms and conditions of the Creative Commons Attribution (CC BY) license (http:// creativecommons.org/licenses/by/4.0/). 